\title{
Skiptir félagslegur stuðningur á vinnustað máli? Tengsl félagslegs stuðnings, starfsánægju, eineltis og áreitni á vinnustað
}

\author{
Hjördís Sigursteinsdóttir og Fjóla Björk Karlsdóttir ${ }^{1}$
}

\begin{abstract}
Ágrip
Mikilvægt er að starfsfólki líði vel á vinnustaðnum enda verja flestir stórum hluta ævinnar par. Vellíðan á vinnustað hefur áhrif bæði á lífsgæði starfsfólks sem og verðmætasköpun fyrirtækja og pjónustugæði stofnanna. Рað eru ýmsir pættir í vinnuumhverfinu sem geta valdið vanlíðan hjá starfsfólki og er einelti og áreitni á vinnustað talin hafa neikvæð áhrif á starfsfólk og par með starfsánægju. Félagslegur stuðningur á vinnustað er hins vegar talinn verndandi páttur gegn neikvæðum páttum í vinnuumhverfinu. Markmið pessarar rannsóknar var að skoða félagslegan stuðning á vinnustað meðal starfsfólks íslenskra sveitarfélaga og tengsl hans við starfsánægju, einelti og kynferðislega og kynbundna áreitni á vinnustað. Rannsóknin byggir á rafrænni spurningalistakönnun frá árinu 2019 meðal starfsfólks 13 íslenskra sveitarfélaga. Í heildina svöruðu 5.182 spurningalistanum að einhverju eða öllu leyti eftir prjár ítrekanir, sem gefur 54\% svarhlutfall. Mun fleiri konur en karlar eru pátttakendur í rannsókninni eða $82 \%$ en pað kynjahlutfall endurspeglar vel kynjahlutfall starfsfólks sveitarfélaganna. Niðurstöðurnar sýna að félagslegur stuðningur mældist 4,1 á skalanum 1-5, hærri meðal kvenna en karla. Starfsánægja mældist einnig 4,1 og um 8\% starfsfólksins hafði orðið yfir einelti á vinnustað og um 2\% fyrir kynferðislegri áreitni og kynbundinni áreitni. Niðurstöðurnar sýna einnig að félagslegur stuðningur hafði jákvæð miðlungs sterk tengsl við starfsánægju starfsfólksins og neikvæð veik tengsl við einelti og kynferðislega og kynbundna áreitni á vinnustað. Álykta má út frá niðurstöðum rannsóknarinnar að félagslegur stuðningur vinnufélaga og yfirmanna sé mikilvægur páttur í starfsánægju starfsfólks sveitarfélaga og sé verndandi páttur gegn einelti og áreitni á vinnustað. Niðurstöðurnar gefa vísbendingar um að stjórnendur og peir sem bera ábyrgð á vellíðan á vinnustað ættu að leggja áherslu á félagslegan stuðning á vinnustað, ekki síst nú á tímum Covid-19 og á vinnustöðum par sem sálfélagslegt vinnuumhverfi er erfitt.
\end{abstract}

\section{Abstract}

Well-being at work is essential for employees as they spend a significant amount of time at work. Well-being at work can affect all aspects of life and organizations' output and the quality of the service provided. Various factors in the work environment can cause discomfort and lack of well-being at work. Bullying and harass-

1 Hjördís Sigursteinsdóttir er dósent við viðskiptadeild Háskólans á Akureyri. Netfang: hjordis@unak.is. Fjóla Björk Karlsdóttir er aðjúnkt við viðskiptadeild Háskólans á Akureyri. Netfang: fjolabjork@unak.is

This work is licensed under a Creative Commons Attribution 4.0 License.

DOI: https://doi.org/10.24122/tve.a.2021.18.2.1 
ment are considered to have a negative effect on employees and thus job satisfaction, but social support at work is considered a protective factor against negative factors in the work environment. The aim of this study is to examine social support at work among employees of Icelandic municipalities and its relationship to job satisfaction, bullying, and sexual and gender-based harassment. The study is based on an online survey from 2019. In total, 5,182 employees answered the questionnaire in part or in full after three reminders (54\% response rate). The majority of participants in the study were women or $82 \%$, but this gender ratio reflects the gender ratio of municipal employees. The results show that social support measured 4.1 on a scale of 1-5, higher among women than men. Job satisfaction was also measured at 4.1 and about $8 \%$ of employees had experienced bullying at work and about $2 \%$ sexual harassment and $2 \%$ gender-based harassment. The results also show that social support has a positive moderately strong correlation with employee job satisfaction and a negative weak correlation with bullying and gender-based harassment at work. Based on the results, it can be concluded that the social support is an important factor connected to job satisfaction and is a protective factor against bullying and harassment at work. It demonstrates that managers and those responsible for well-being in the workplace should focus on social support at work, especially now when the psychosocial work environment is fragile due to covid-19.

JEL flokkun: J28; J81; M12; M14; M54

Lykilorð: Líðan á vinnustað; félagslegur stuðningur; einelti; starfsánægja; áreitni

Keywords: Well-being at work; social support; harassment; job satisfaction; bullying

\section{Social support, job satisfaction, bullying, and harassment at work.}

\section{Inngangur}

Vellíðan á vinnustað skiptir máli, ekki bara fyrir starfsfólkið heldur vinnustaðinn líka, en ýmsir pættir í vinnuumhverfinu geta valdið neikvæðum áhrifum á heilsu og líðan starfsfólksins. Einelti og áreitni eru hluti af pessum neikvæðu páttum í vinnuumhverfinu sem hefur neikvæð áhrif á heilsu, líðan og starfsánægju starfsfólksins (Nielsen og Einarsen, 2018) en rannsóknir sýna að félagslegur stuðningur á vinnustað getur verið verndandi páttur gegn peim (Fang, Hsiao, Fang og Chen, 2021; Hjördís Sigursteinsdóttir, Guðbjörg Linda Rafnsdóttir og Guðbjörg Andrea Jónsdóttir, 2020; Rossiter og Sochos, 2018). Félagslegur stuðningur á vinnustað (e. social support at work) felur í sér hjálpleg samskipti frá yfirmanni og vinnufélögum á vinnustað og er veittur af umhyggju, trausti og virðingu (Fujishiro og Heaney, 2007; Karasek og Theorell, 1990). Segja má að mikilvægi pess að skoða félagslegan stuðning á vinnustað í tengslum við vellíðan á vinnustað endurspeglist í priðju víddinni við líkan Karasek frá árinu 1979 um starfskröfur og sjálfræði í starfi, p.e. að vellíðan í vinnu byggist á premur víddum, starfskröfum, sjálfræði og félagslegum stuðningi (Johnson og Hall, 1988; Karasek og Theorell, 1990). Samkvæmt Rasmussen, Hansen og Nielsen (2011) er lítill félagslegur stuðningur frá yfirmönnum og vinnufélögum streituvaldandi en mikill stuðningur stuðlar að vellíðan og peir nefna félagslegan stuðning sem einn af sex páttum í vinnuumhverfinu sem stjórnendur purfi að hlúa að til að auka vellíðan starfsfólks á vinnustaðnum. Í pessu ljósi er megintilgangur pessarar rannsóknar að skoða félagslegan stuðning starfsfólks íslenskra sveitarfélaga og tengsl hans við starfsfánægju, einelti og áreitni á vinnustað. Starfsfólk íslenskra veitarfélaga er áhugaverður hópur að skoða par sem íslensk sveitarfélög eru einn stærsti vinnuveitandi landsins með konur í miklum meirihluta starfsfólksins (Samband íslenskra sveitarfélaga, ó.d.).

Starfsánægja (e. job satisfaction) er hugtak sem tengist vellíðan á vinnustað en pað felur 
í sér viðhorf til vinnu og er bæði huglægt og tilfinningalegt viðbragð starfsfólks gagnvart starfi sínu (Locke, 1969). Rannsóknir sýna að vinnuskilyrði hafa mest áhrif á starfsánægju og starfsmannaveltu meðal opinbers starfsfólks, sem og félagsleg tengsl við vinnufélaga og yfirmenn, starfsanda, möguleika á stöðuhækkun og tækifæri til starfspróunar (Borzaga og Tortia, 2006; Ellickson og Logsdon, 2002; Kim, 2002; Wright og Davis, 2003). Af pessu má sjá að félagslegur stuðningur hefur jákvæð áhrif á starfsánægju en hins vegar er lítið um rannsóknir sem skoðað hafa tengsl eineltis og áreitni og félagslegs stuðnings á vinnustað og pá hversu verndandi páttur félagslegur stuðningur getur verið fyrir starfsfólk sem verður fyrir slíkri óæskilegri hegðun á vinnustað.

\section{Félagslegur stuðningur og starfsánægja}

Fram hafa komið ýmsar skilgreiningar á félagslegum stuðningi á vinnustað og áhrifum hans á starfsfólkið. Cobb (1976) skilgreinir félagslegan stuðning sem upplýsingar sem einstaklingur meðtekur um að öðrum sé annt um hann og hann sé metinn sem hluti af ákveðnu teymi og hafi sömu skuldbindingar og teymið. Hobfoll og Stokes (1988, bls. 499) taka í sama streng og skilgreina félagslegan stuðning sem samband eða félagsleg samskipti sem veita aðilum aðstoð og umhyggju og mynda ástrík tengsl milli einstaklinga eða hópa. Upplýsingagjöf inni á vinnustað fellur einnig undir félagslegan stuðning og er par átt við ráðgjöf og leiðsögn enda mikil pörf á úrræðum inni á vinnustöðum til að takast á við auknar kröfur og álag í starfi (Seiger og Wiese, 2009). Félagslegur stuðningur eykur væntingar starfsfólks til vinnu og hjálpar til við að mæta pörfum peirra fyrir virðingu, tilfinningalegan stuðning og sjálfstraust, sem leiðir til jákvæðrar vinnuhegðunar. Fyrri rannsóknir hafa sýnt að pví meiri félagslegur stuðningur sem starfsfólk fær eða skynjar, pví betur mun pað geta tekið pátt í starfi sínu og upplifað jákvæðari tilfinningar í vinnunni sem leiðir til meiri starfsánægju (Lan o.fl., 2018). Rousseau og Aubé (2010) benda á að félagslegur stuðningur á vinnustað getur stuðlað að jákvæðari starfsreynslu og stuðli pannig að meiri skuldbindingu við vinnustaðinn. Samkvæmt nýrri rannsókn Kiema-Junes og félaga (2020) tengist félagslegur stuðningur á vinnustað helgun í starfi pannig að eftir pví sem stuðningurinn er meiri pví meira er starfsfólkið helgað starfi sínu.

Skipta má félagslegum stuðningia vinnustað í tvennt, annars vegar stuðning frá vinnufélögum og hins vegar stuðning frá yfirmönnum. Stuðningur frá vinnufélögum vísar til pess að hve miklu leyti vinnufélagar veita félagslegan og tilfinningalegan stuðning og traust til annarra vinnufélaga sem og hjálp með verkefni (Karasek og Theorell, 1990). Stuðningur frá yfirmönnum vísar aftur á móti til tilfinningalegs stuðnings eins og samkenndar, endurgjafar og leiðbeiningar og stuðning við pætti eins og úrræði á vinnustað og framgang í starfi (Bhanthumnavian, 2003). McGuire (2007) rannsakaði félagslegan stuðning á vinnustöðum og greindi að algengasta stuðningsformið innan peirra voru almenn samtöl starfsfólks um persónulegt líf og reynslu (e. sharing) og hlustun (e. listening). Slíkur stuðningur felst fyrst og fremst í að hlusta og veitir starfsfólki ákveðna losun á erfiðum tilfinningum sem stuðlar að bættri líðan starfsfólks. Með góðum félagslegum stuðningi á vinnustað myndast gott samband milli starfsfólks sem bætir starfsumhverfi pess og gefur pví pá tilfinningu аð pað tilheyri vinnustaðnum (Ahmad og Veerapamdian, 2012; Hayes, Bonner og Pryor, 2010).

Rannsóknir sýna að konur veiti oftar félagslegan stuðning á vinnustað en karlar en einnig kemur fram að konur fá oftar en karlar félagslegan stuðning á vinnustað (Beehr ofl., 2003; Fuhrer o.fl., 1999). Rannsókn Hjördísar Sigursteinsdóttur (2010) meðal starfsfólks íslenskra sveitarfélaga sýnir að konur telja sig oftar fá félagslegan stuðning á vinnustað en karlar og pá skipti engu máli hvort horft er til stuðnings frá vinnufélögum eða yfirmönnum. Jafnframt sýna rannsóknir að félagslegur stuðningur á vinnustað hefur jákvæðari áhrif á karla en konur (Fuhrer og Stansfeld, 2002; Plaisier o.fl., 2007; Schwarzer og Gutiérrez-Dona, 2005). Pessi mismunandi áhrif félagslegs stuðnings á konur og karla hafa rannsóknir skýrt pannig að tilfinningalegt álag kvenna við að veita og taka við fé- 
lagslegum stuðningi frá vinnufélögum er mikið, sem leiðir til pess að ávinningur peirra sjálfra af félagslegum stuðningi frá vinnufélögum verður ekki eins mikill og hjá körlum (Schwarzer og Gutiérrez-Dona, 2005; Walen og Lachman, 2000).

Starfsánægja er talin lykilpáttur í líðan starfsfólks á vinnustað og hefur áhrif á fjarveru pess og frammistöðu sem og starfsmannaveltu vinnustaðarins (Locke, 1969). Samkvæmt Locke (1969) endurspeglar starfsánægja jákvætt tilfinningalegt ástand sem er afleiðing af skynjun og reynslu starfsfólks af eigin starfi. Starfsfólk gæti fundið fyrir mismikilli ánægju eða óánægju í sama starfinu eða við mismunandi hluta starfsins. Pví væri starfsánægja eða starfsóánægja flókið tilfinningalegt viðbragð gagnvart starfinu. Kalleberg (1977) tekur undir með Locke og telur gildi (e. work values) ásamt ávinningi af ýmsum páttum vinnunnar hafi umtalsverð áhrif á starfsánægju. Par á meðal félagslegur stuðningur á vinnustað, sem hann kallar priðju víddina, og kemur fram í vinsemd og hjálpsemi. Saari og Judge (2004) tóku í sama streng og Locke og vildu meina að pegar einstaklingur hugsar pá upplifir hann tilfinningar tengt pví sem hann hugsar um. Áður hafði starfsánægja oft verið mæld með ýmsum áhrifapáttum úr starfsumhverfinu, líkt og Kalleberg (1977) talar um, en Saari og Judge (2004) vildu meina að pað væri ekki nauðsynlegt að spyrja margra spurninga um fjölda pátta í starfsumhverfinu til að meta starfsánægju starfsfólks heldur væri fullnægjandi að spyrja einnar spurningar um starfsánægju pví slík mæling ætti rétt á sér og væri marktæk. Stundum getur verið erfitt að útskýra hvers vegna starfsfólk sem vinnur sama starf og í sama starfsumhverfi upplifir mismunandi starfsánægju (Kalleberg, 1977). Einn peirra áhrifapátta sem rannsóknir hafa skoðað eru áhrif kyns á starfsánægju og eru niðurstöðurnar mismunandi. Sumar rannsóknir greina engan mun á milli kvenna og karla og starfsánægju (Durst og DeSantis, 1997; Ellickson og Logsdon, 2001) á meðan aðrar rannsóknir greina meiri starfsánægju hjá konum en körlum (Aletraris, 2010; Kim, 2005; Steijn, 2004). Í kjölfar heimsfaraldurs er til dæmis áhugavert að minnast á niðurstöður Feng og Savani (2020) sem rannsökuðu starfsánægju útivinnandi foreldra (e. dualcareer parents) fyrir og eftir tilkomu heimsfaraldursins par sem starfsfólk var fast heima fyrir (e. lockdown). Niðurstöður peirra sýna engan mun á starfsánægju kvenna og karla fyrir heimsfaraldurinn en eftir tilkomu hans greindust konur með minni starfsánægju en karlar.

Félagslegur stuðningur yfirmanna og vinnufélaga getur haft mikil áhrif á starfsánægju á vinnustað (Kucharska og Bedford, 2019; Mérida-López, Extremera, Quintana-Ortis og Rey, 2019; Ng og Sorensen, 2008; Pinna ofl., 2020). Nýleg rannsókn Pinna og félaga (2020) sýnir að félagslegur stuðningur, bæði frá yfirmönnum og vinnufélögum, hefur bein áhrif á starfsánægju á vinnustað. Rannsókn Kucharska og Bedford (2019) sýnir jafnframt sterk tengsl milli félagslegs stuðnings og starfsánægju tengt vilja starfsfólks til að veita samstarfsfólki sínu aðstoð og aðgang að sinni sérpekkingu og að starfsánægja skapi jákvætt viðhorf og hollustu gagnvart vinnustaðnum. Félagslegur stuðningur og starfsánægja hefur einnig verið tengd við lífsgæði en Yuh og Choi (2017) skoðuðu tengsl félagslegs stuðnings, starfsánægju og lífsgæða hjá leikskólakennurum. Niðurstöður peirra sýna jákvæð tengsl milli félagslegs stuðnings frá bæði yfirmönnum og vinnufélögum við starfsánægju og stuðningur frá fjölskyldu spáði fyrir um lífsgæði pegar búið var að taka tillit til aldurs og hjúskaparstöðu. Peir álykta að félagslegur stuðningur skipti verulegu máli fyrir leikskólakennarana á vinnustaðnum sem og almenn lífsgæði peirra.

\section{Einelti og áreitni á vinnustað og félagslegur stuðningur}

Fræðimenn eru ekki á einu máli um hvernig skilgreina á hugtakið einelti á vinnustað en flestar skilgreiningar eiga pað pó sameiginlegt að snúast um að starfsfólk verði fyrir síendurtekinni neikvæðri háttsemi eða hegðun af hálfu annars eða annarra einstaklinga á vinnustað (Nielsen og Einarsen, 2018). Samkvæmt reglugerð nr. 1009/2015 um aðgerðir gegn einelti, kynferðislegri áreitni, kynbundinni áreitni og ofbeldi á vinnustöðum er ein- 
elti tilgreint sem ámælisverð eða síendurtekin tilhlýðileg háttsemi, athöfn eða hegðun sem niðurlægir, gerir lítið úr, móðgar, særir, mismunar eða ógnar öðrum og veldur vanlíðan. Pá er ekki verið að tengja einelti við skoðanaágreining eða hagsmunaárekstra sem komið geta upp á vinnustöðum. Í sömu reglugerð kemur fram að kynferðisleg áreitni er hvers kyns kynferðisleg hegðun sem er í ópökk pess sem fyrir henni verður. Áreitni hefur pann tilgang eða áhrif að misbjóða virðingu viðkomandi, einkum pegar hegðunin leiðir til ógnandi, fjandsamlegra eða niðurlægjandi aðstæðna en hegðunin getur verið orðbundin, táknræn og/eða líkamleg. Kynbundin áreitni telst vera hegðun sem tengist kyni pess sem fyrir henni verður og er í ópökk viðkomandi. Áreitni getur skapað aðstæður sem eru ógnandi, fjandsamlegar, niðurlægjandi, auðmýkjandi eða móðgandi fyrir viðkomandi (Reglugerð nr. 1009/2015).

Rannsóknir síðasta áratuginn á einelti á Íslandi sýna að einelti á vinnustöðum mælist frá 10\% til ríflega 20\% (Ásta Snorradóttir o.fl., 2020; Hjördís Sigursteinsdóttir, 2013; Hjördís Sigursteinsdóttir, 2017; Hjördís Sigursteinsdóttir o.fl., 2020). Í nýlegri rannsókn Ástu Snorradóttur og félaga (2020), sem gerð var meðal íslensku pjóðarinnar óháð atvinnugreinum og atvinnutengdum stéttum starfsfólks, greina ríflega 2 af hverjum 10 pátttakendum frá pví að hafa orðið fyrir einelti einhvern tímann á starfsævinni. Jafnframt greina aðilar sem urðu fyrir einelti á vinnustað frá minni starfsánægju, peir meta líkamlega og andlega heilsu sína verri og eru líklegri til að hætta í starfi en peir sem ekki hafa upplifað einelti á vinnustað. Rannsókn Ástu Snorradóttur og félaga (2020) sýnir jafnframt að 16\% pátttakenda hafa orðið fyrir kynferðislegri áreitni, eða 25\% kvenna og tæp 7\% karla, og einn af hverjum tíu hefur upplifað kynbundna áreitni, konur í meira mæli en karlar. Enn fremur sýna niðurstöðurnar að einstaklingar sem hafa orðið fyrir kynferðislegri áreitni telja andlega heilsu sína verri en peir sem ekki hafa orðið fyrir kynferðislegri áreitni. Rannsókn sem Hjördís Sigursteinsdóttir (2017) gerði á einelti, áreitni og ofbeldi á vinnustað meðal félagsmanna Kennarasambands Íslands leiðir í ljós að ríflega 10\% félagsmanna hafa orðið fyrir einelti á vinnustað á árunum 2015 til 2017 og reyndist hlutfall karla hærra en kvenna eða rúm 12\% á móti 10\% kvenna. Í sömu rannsókn greina 2-3\% frá pví að hafa orðið fyrir kynferðislegri áreitni eða kynbundinni áreitni á vinnustað. Hlutfallið er mjög svipað hjá konum og körlum.

Samkvæmt fyrri rannsóknum telja polendur eineltis að peir fái síður félagslegan stuðning á vinnustað en annað starfsfólk sem ekki hefur orðið fyrir einelti og polendur eineltis eru ekki eins ánægðir með stjórnendur vinnustaðarins og aðrir (Guðbjörg Linda Rafnsdóttir og Kristinn Tómasson, 2004; Hjördís Sigursteinsdóttir, 2013). Í langtímarannsókn Hjördísar Sigursteinsdóttur og félaga (2020) meðal starfsfólks í menntageiranum og umönnunarpjónustu hjá íslenskum sveitarfélögum kemur fram að einelti og áreitni hefur aukist í kjölfar efnahagshrunsins 2008. Einelti mælist um 8\% árið 2010 en jókst í 20\% árið 2015 og kynferðisleg áreitni mælist á bilinu 3-5\% og kynbundin áreitni á bilinu 4-7\% á pessum árum. Jafnframt sýna pær niðurstöður að starfsfólk á vinnustöðum par sem einhverjum hafði verið sagt upp störfum vegna efnahagshrunsins, á vinnustöðum með meiri starfskröfur, meiri hlutverkaágreininga og minni félagslegan stuðning, er líklegra að starfsfólk verði fyrir einelti og áreitni á vinnustað en starfsfólk á öðrum vinnustöðum. Ekki kom fram munur á konum og körlum í peirri rannsókn. Út frá pessum niðurstöðum má álykta að par sem áhrifa niðurskurðar geti varið í langan tíma purfi að huga vel að afleiðingum slíkra aðgerða par sem efnahagskreppur hafa tilhneigingu til að eiga sér stað reglulega eins og til dæmis nú árið 2021 vegna Covid-19. Félagslegur stuðningur hefur reynst verndandi páttur gegn einelti og áreitni og pví má ætla að pað sé mikilvægt að leggja sérstaka áherslu á félagslegan stuðning á vinnustöðum par sem sálfélagslegt starfsumhverfi er strembið og á óvissutímum sem pessum.

Ana (2015) og Gransta (2015) benda á að ein af skyldum vinnuveitenda sé að tryggja vinnuumhverfi sem er laust við óæskilega hegðun eins og einelti og áreitni á vinnustað. 
Mikill meirihluti polenda eineltis á vinnustað upplifir að orsök eineltisins byggi að mestu eða öllu leyti á vinnuumhverfinu (Zapf, 1999). Ábyrgð vinnuveitenda kemur jafnframt skýrt fram í í 6.gr. reglugerðar nr. 1009/2015 en par kemur fram að: „Atvinnurekanda ber skylda til að láta einelti, kynferðislega áreitni, kynbundna áreitni eða ofbeldi á vinnustað ekki viðgangast á vinnustað og skal hann gera starfsmönnum ljóst með skýrum hætti að slík hegðun sé óheimil“. Kwan, Tuckey og Dollard (2016) telja að starfsfólk geti betur tekist á við einelti á vinnustað ef vinnuumhverfið sé pannig úr garði gert að stjórnendur hugi vel að andlegri heilsu starfsfólksins, leggi mikið upp úr góðum samskiptum á vinnustað og að starfsfólkið taki pátt í málefnum sem varðar andlega heilsu pess og öryggi. Ásta Snorradóttir og Kristinn Tómasson (2018) gerðu rannsókn á einelti á íslenskum vinnustöðum par sem fram kemur að mál sem bárust Vinnueftirlitinu eru flest langvinn og í flestum tilfellum er yfirmaður tilgreindur sem gerandi. Jafnframt kemur fram í sömu rannsókn að gera megi ráð fyrir að ef vinnustaðir og yfirmenn bregðist ekki við einelti með markvissum aðgerðum pá hafi eineltið umtalsverðar afleiðingar bæði fyrir starfsmanninn, til að mynda með aukinni veikindafjarveru, og fyrir fyrirtækið eða stofnunina, með tilheyrandi starfsmannaveltu og kostnaði.

Starfsfólk sem upplifir einelti eða áreitni á vinnustað eru af öllum kynjum og gerendur eru oftast vinnufélagar eða yfirmenn á vinnustaðnum. Rannsóknir sýna fram á að konur sem starfa í karllægum starfsstéttum verði frekar fyrir einelti og áreitni á vinnustað en aðrar konur og pær eru líklegri til að segja upp starfi sínu vegna pessa. Jafnframt hafa efnahagslegar lægðir áhrif á tíðni eineltis og áreitni á vinnustöðum og mælist hlutfall peirra sem verða fyrir einelti eða áreitni á vinnustað hærra á krísutímabilum (Giorgi, et al. 2020; Yang og Katz, 2020). Pví er jafnvel enn mikilvægara að fylgjast með líðan starfsfólksins á vinnustað á erfiðum tímum sem pessum pegar Covid-19 faraldurinn er enn ríkjandi um allan heim.

Félagslegur stuðningur tengdur einelti og áreitni á vinnustað hefur lítið verið rannsakaður en pó eru nokkrar rannsóknir í seinni tíð sem hafa komið fram á sjónarsviðið. Nielsen og félagar (2020) rannsökuðu hvort félagslegur stuðningur á vinnustað myndi draga úr áhrifum eineltis eða vernda starfsmenn gegn einelti og komast að peirri niðurstöðu að svo sé. Rannsóknin náði til 10.627 starfsmanna, par af er um 60\% svarenda konur, á 96 mismunandi vinnustöðum í Noregi og sýnir rannsóknin jafnframt fram á að stuðningur yfirmanna hefur jákvæð áhrif á bæði konur og karla en stuðningur vinnufélaga hefur jákvæðari áhrif á konur en karla. Enn fremur sýnir rannsókn peirra að stuðningur utan við vinnustaðinn verndar ekki starfsmenn gegn einelti á vinnustað. Rannsóknin gefur jafnframt vísbendingar um að félagslegur stuðningur dragi úr áhrifum eineltis á heilsu starfsfólks og vinnugetu, sér í lagi stuðningur yfirmanna. Rannsókn Fang og félaga (2021) á áhrifum félagslegs stuðnings á einelti og heilsu 238 hjúkrunarfræðinga á spítala í Kína sýnir að félagslegur stuðningur dregur úr áhrifum eineltis á heilsu starfsfólksins pannig að meiri félagslegur stuðningur á vinnustað tengist beint betri heilsu. Rossiter og Sochos (2018) rannsökuðu áhrif félagslegs stuðnings á einelti og kulnun 222 starfsmanna í mismunandi fyrirtækjum og atvinnugreinum. Rannsóknin sýnir að stuðningur vinnufélaga og yfirmanna dró úr áhrifum eineltis og kulnunar í starfi en félagslegur stuðningur er par skilgreindur sem ápreifanlegur stuðningur (e. instrumental support) og tilfinningalegur/sálrænn stuðningur (e. emotional support). Svo virðist sem bæði ápreifanlegur og tilfinningalegur stuðningur dragi úr áhrifum eineltis sem leiðir til kulnunar. Ápreifanlegur stuðningur dregur meira úr áhrifum eineltis á kaldhæðni starfsmanna (e. cynicism) á meðan að tilfinningalegur stuðningur dregur meira úr áhrifum eineltis sem leiðir til tilfinningalegrar örmögnunar.

Í ljósi pessa var sett fram rannsóknarspurningin: Hver eru tengsl félagslegs stuðnings á vinnustað við starfsánægju, einelti og kynferðislega og kynbundna áreitni á vinnustað meðal starfsfólks íslenskra sveitarfélaga? Með pví að svara pessari rannsóknarspurningu er leitast við að fá upplýsingar um áhrif félagslegs stuðnings á líðan starfsfólks sveitarfélaga á vinnustaðnum út frá starfsánægju, einelti og áreitni á vinnustað. 


\section{Gögn og aðferðir}

Pessi grein byggir á gögnum sem safnað var meðal starfsfólks 13 íslenskra sveitarfélaga árið 2019. Um var að ræða megindlega aðferðarfræði par sem rafrænn spurningalisti var lagður fyrir starfsfólk sveitarfélaganna í peim tilgangi að safna upplýsingum um viðhorf og líðan starfsfólksins á vinnustaðnum.

\subsection{Framkvæmd}

Rannsóknin var framkvæmd í samstarfi við sveitarfélögin sem tóku pátt í rannsókninni og voru pað mannauðsstjórar peirra sem útveguðu rannsakendum netföng starfsfólksins. Sett voru skilyrði um að starfsmaður pyrfti að vera í að minnsta kosti $50 \%$ starfshlutfalli og vera 18 ára eða eldri. Á vordögum 2019 var sendur tölvupóstur á starfsfólkið par sem óskað var eftir pátttöku í rannsókninni. Pátttaka var sampykkt með pví að smella á meðfylgjandi tengil og senda inn svör við spurningalistanum. Áréttað var að svör yrðu ekki rakin til einstakra starfsmanna og einnig að öllum var frjálst að hafna pátttöku í rannsókninni með pví að hunsa tölvupóstinn án útskýringa. Beiðni um pátttöku í rannsókninni var fylgt eftir með premur ítrekunum til peirra sem ekki höfðu svarað spurningalistanum á peim tímapunkti sem ítrekun átti sér stað.

\subsection{Pátttakendur}

Pátttakendur rannsóknarinnar komu frá 13 sveitarfélögum, fjórum sveitarfélögum á höfuðborgarsvæðinu og níu af landsbyggðinni. Spurningalistinn var sendur í tölvupósti á 9.548 starfsmenn og bárust svör frá 5.182 starfsmönnum sem pýðir að svarhlutfall var $54,2 \%$. Hlutfall kvenna í rannsókninni er $82 \%$ en pað hlutfall endurspeglar vel kynjaskiptingu starfsfólks sveitarfélaganna.

\subsection{Mælitæki}

Spurningar í spurningalistanum eru allt spurningar sem hafa verið notaðar í öðrum vinnustaðarannsóknum par sem verið er að mæla líðan á vinnustaðnum.

Félagslegur stuðningur var mældur með fjórum spurningum; (1) „Færð pú stuðning og hjálp með verkefni hjá vinnufélögum pínum, ef á parf að halda?“, (2) „Færð pú stuðning og hjálp með verkefni hjá næsta yfirmanni pínum, ef á parf að halda?“, (3) „Eru vinnufélagarnir fúsir til að hlusta á vandamál sem við er að glíma í vinnunni, ef á parf að halda?", (4) „Er næsti yfirmaður pinn fús til að hlusta á vandamál sem við er að glíma í vinnunni, ef á parf að halda?“. Gefnir voru fimm svarmöguleikar, frá (1) mjög sjaldan eða aldrei og аð (5) mjög oft eða alltaf. Alfastuðullinn fyrir pessar fjórar spurningar var 0,862.

Starfsánægja var mæld með fullyrðingunni; „,Pegar á heildina er litið er ég ánægð(ur) í starfi mínu“. Gefnir voru fimm svarmöguleikar, frá (1) mjög ósammála og að (5) mjög sammála.

Einelti var metið með spurningunni; „Hefur pú orðið fyrir einelti á núverandi vinnustað á síðastliðnum tveimur árum?“. Petta var já/nei spurning en einelti var útskýrt fyrir pátttakendum sem síendurtekin hegðun sem fæli í sér særandi og/eða niðurlægjandi framkomu gagnvart einstaklingi.

Kynferðisleg áreitni var mæld með spurningunni; „Hefur pú orðið fyrir kynferðislegri áreitni á núverandi vinnustað á síðastliðnum tveimur árum?“. Petta var já/nei spurning en kynferðisleg áreitni var útskýrð fyrir pátttakendum sem hegðun sem fæli í sér kynferðislegar athafnir, hegðun eða athugasemdir sem beinast að einstaklingi og eru gegn hans sampykki eða vilja.

Kynbundin áreitni var mæld með spurningunni; „Hefur pú orðið fyrir kynbundinni áreitni á núverandi vinnustað á síðastliðnum tveimur árum?“. Petta var já/nei spurning en kynbundin áreitni var útskýrð fyrir pátttakendum sem særandi eða niðurlægjandi framkoma í garð kvenna eða karla vegna kyns peirra, án pess pó að vera kynferðisleg. 


\subsection{Greining gagna}

Niðurstöður eru settar fram sem fjöldatölur, hlutfall, meðaltöl og staðalfrávik. Til pess að skoða mun á viðhorfum kvenna og karla á félagslegum stuðningi, starfsánægju, einelti og áreitni var notað kí-kvaðratpróf. Til að skoða tengsl milli félagslegs stuðnings og starfsánægju var notað Pearsons's R-fylgnipróf en til að skoða tengsl félagslegs stuðnings, eineltis og áreitni var notað Spearman's rho fylgnipróf. Stuðst var við skilgreiningu Cohens (1988, bls. 79-81) til að meta hvort um veik $(0,10-0,29)$, miðlungssterk $(0,30-0,49)$ eða sterk tengsl $(0,50-1,0)$ væri að ræða. Einnig var notað t-próf óháðra til að skoða hvort peir sem höfðu orðið fyrir einelti eða áreitni töldu sig fá meiri eða minni félagslegan stuðning á vinnustað en peir sem ekki höfðu orðið fyrir slíku. Tölfræði var unnin í SPSS 22 og marktæknikrafa var 0,05.

\section{Niðurstöður}

\subsection{Félagslegur stuðningur á vinnustað}

Á skalanum 1-5 pá mældist meðaltal fyrir félagslegan stuðning á vinnustað 4,10 $(s f=0,8)$. Meðaltalið fyrir félagslegan stuðning frá vinnufélögum mældist 4,17 (sf =0,8) og 4,06 (sf $=1,0)$ fyrir félagslegan stuðning yfirmanna. Konur $(M=4,2 ; s f=0,8)$ töldu sig oftar fá félagslegan stuðning en $\operatorname{karlar}(M=3,9 ; s f=0,9)$ og reyndist munurinn milli kvenna og karla marktækur samkvæmt óháðu t-prófi $\left(t_{(4274)}=6,5 ; p<0,05\right)$. Konur töldu sig einnig fá oftar félagslegan stuðning en karlar frá bæði vinnufélögum $(M=4,2 / 4,0 ; s f=0,8 / 0,9)\left(t_{(4270)}=7,3\right.$; $p<0,05)$ og yfirmönnum $(M=4,1 / 3,9 ; s f=1,0 / 1,0)\left(t_{(4268)}=4,8 ; p<0,05\right)$.

Tafla 1 sýnir niðurstöður fyrir spurningar um félagslegan stuðning á vinnustað eftir kyni. Sjá má að tæp 45\% (+-2,2\%) svarenda fékk mjög oft eða alltaf stuðning og hjálp með verkefni frá vinnufélögum pegar á pyrfti að halda og rúm 32\% (+-2,5\%) til viðbótar fremur oft. Aðeins færri eða um 42\% (+-2,3\%) töldu sig mjög oft eða alltaf fá stuðning og hjálp með verkefni hjá næsta yfirmanni sínum ef á pyrfti að halda og rúm 28\% (+-2,5\%) til viðbótar fremur oft. Konur töldu í meira mæli en karlar að pær ættu stuðning bæði frá vinnufélögum og yfirmönnum vísan $(p<0,05)$. Rúm $44 \%(+-2,4 \%)$ taldi vinnufélagana mjög oft eða alltaf tilbúna til að hlusta á vandamál sem við var að glíma í vinnunni ef á pyrfti að halda og tæp 36\% (+-2,7\%) til viðbótar fremur oft. Aðeins fleiri eða tæp 48\% (+-2,5\%) töldu næsta yfirmann mjög oft eða alltaf tilbúinn til að hlusta á vandamál sem við var að glíma í vinnunni ef á pyrfti að halda og 30\% (+-2,8\%) til viðbótar fremur oft. Konur töldu í meira mæli en karlar að vinnufélagar og næsti yfirmaður væru tilbúnir til að hlusta á vandamál ef á pyrfti að halda $(p<0,05)$.

Tafla 1. Félagslegur stuðningur á vinnustað eftir kyni

\begin{tabular}{|c|c|c|c|c|c|c|c|}
\hline & & Fjöldi & $\begin{array}{l}\text { Mjög sjaldan } \\
\text { eða aldrei } \\
\%\end{array}$ & $\begin{array}{l}\text { Fremur } \\
\text { sjaldan } \\
\%\end{array}$ & $\begin{array}{l}\text { Stund- } \\
\text { um } \\
\%\end{array}$ & $\begin{array}{l}\text { Frem- } \\
\text { ur oft } \\
\quad \%\end{array}$ & $\begin{array}{l}\text { Mjög oft } \\
\text { eða alltaf } \\
\quad \%\end{array}$ \\
\hline \multirow{3}{*}{$\begin{array}{l}\text { Færð pú stuðning og hjálp með verkefni hjá } \\
\text { vinnufélögum ef á parf að halda?* }\end{array}$} & Allir & 4267 & 1,2 & 3,9 & 18,0 & 32,4 & 44,5 \\
\hline & Konur & 3479 & 1,1 & 3,4 & 16,8 & 32,6 & 46,1 \\
\hline & Karlar & 788 & 1,5 & 6,5 & 23,5 & 31,3 & 37,2 \\
\hline \multirow{3}{*}{$\begin{array}{l}\text { Færð pú stuðning og hjálp með verkefni hjá } \\
\text { næsta yfirmanni pínum ef á parf að halda?** }\end{array}$} & Allir & 4261 & 3,6 & 7,4 & 18,6 & 28,4 & 42,0 \\
\hline & Konur & 3475 & 3,4 & 7,0 & 17,4 & 28,4 & 43,8 \\
\hline & Karlar & 786 & 4,3 & 9,0 & 23,7 & 28,6 & 34,5 \\
\hline \multirow{3}{*}{$\begin{array}{l}\text { Eru vinnufélagarnir fúsir til að hlusta á vanda- } \\
\text { mál sem við er að glíma í vinnunni ef á parf að } \\
\text { halda?*** }\end{array}$} & Allir & 4240 & 1,1 & 3,0 & 15,8 & 35,9 & 44,2 \\
\hline & Konur & 3461 & 1,1 & 2,7 & 14,5 & 34,8 & 46,9 \\
\hline & Karlar & 628 & 1,1 & 5,7 & 2,6 & 50,6 & 40,0 \\
\hline \multirow{3}{*}{$\begin{array}{l}\text { Er næsti yfirmaður pinn fús til að hlusta á } \\
\text { vandamál sem við er að glíma í vinnunni ef á } \\
\text { parf að halda?**** }\end{array}$} & Allir & 4253 & 2,4 & 5,6 & 14,4 & 30,1 & 47,5 \\
\hline & Konur & 3468 & 2,3 & 5,5 & 13,8 & 29,0 & 49,4 \\
\hline & Karlar & 785 & 2,9 & 6,0 & 16,7 & 35,2 & 39,2 \\
\hline
\end{tabular}

${ }^{*} \chi 2(4, \mathrm{~N}=4267)=44,5 ; p<0,05{ }^{* *} \chi^{2}(4, \mathrm{~N}=4261)=31,7 ; p<0,05{ }^{* * *} \chi 2(4, \mathrm{~N}=4240)=64,8 ; p<0,05{ }^{* * * *} \chi 2(4, \mathrm{~N}=4253)=26,9 ; p<0,05$ 


\subsection{Starfsánægja, einelti og áreitni á vinnustað}

Almennt má segja að líðanin á vinnustaðnum hafi verið nokkuð góð. Starfsánægja mældist að meðaltali $4,13(s f=0,8)$ af 5,0 mögulegum en pó höfðu tæp 8\% (+-2,9\%) orðið fyrir einelti á núverandi vinnustað og um $2 \%(+-3,0 \%)$ fyrir kynbundinni áreitni sem og kynferðislegri áreitni.

Tafla 2 sýnir niðurstöður fyrir starfsánægju svarenda eftir kyni. Sjá má að tæp 36\% (+-2,3\%) voru mjög oft eða alltaf, pegar á heildina er litið, ánægð í starfi sínu og rúm 48\% (+-2,1\%) til viðbótar frekar oft ánægð. Fram kom marktækur munur á starfsánægju kvenna og karla pannig að hlutfallslega fleiri konur voru oftar ánægðari í starfi sínu en karlar $(p<0,05)$.

Tafla 3 sýnir niðurstöður fyrir einelti og áreitni á núverandi vinnustað eftir kyni. Um $8 \%$ (+-2,9\%) svarenda hafði orðið fyrir einelti á núverandi vinnustað á síðastliðnum tveimur árum. Aðeins hærra hlutfall kvenna en karla eða 8\% (+-6,8\%) á móti tæpum 7\% (+-3,2\%) karla hafði orðið fyrir einelti á núverandi vinnustað en munurinn var ekki marktækur. Rúm 2\% (+-3,0\%) svarenda hafði orðið fyrir kynferðislegri áreitni á núverandi vinnustað á síðastliðnum tveimur árum, aðeins hærra hlutfall meðal kvenna en karla en munurinn reyndist ekki marktækur. Mjög svipað hlutfall hafði orðið fyrir kynbundinni áreitni á núverandi vinnustað eins og kynferðislegri áreitni eða 2,2\% (+-3,0\%) og einnig hafði aðeins hærra hlutfall kvenna en karla orðið fyrir kynbundinni áreitni á núverandi vinnustað á síðastliðnum tveimur árum eða 2,4\% (+-3,3\%) á móti 1,6\% karla (+-7,0\%). Munurinn var pó ekki marktækur.

Tafla 2. Starfsánægja eftir kyni

\begin{tabular}{llcccccc}
\hline & Fjöldi & $\begin{array}{c}\text { Mjög sjaldan } \\
\text { eða aldrei } \\
\%\end{array}$ & $\begin{array}{c}\text { Frekar } \\
\text { sjaldan } \\
\%\end{array}$ & $\begin{array}{c}\text { Stundum } \\
\%\end{array}$ & $\begin{array}{c}\text { Frekar oft } \\
\%\end{array}$ & $\begin{array}{c}\text { Mjög oft } \\
\text { eða alltaf } \\
\%\end{array}$ \\
\hline begar á heildina er & Allir & 4554 & 1,1 & 3,8 & 11,2 & 48,3 & 35,6 \\
litið er ég ánægð(ur) í & Konur & 3712 & 1,2 & 3,7 & 10,5 & 48,3 & 36,3 \\
starfi mínu* & Karlar & 842 & 0,8 & 4,5 & 14,5 & 47,6 & 32,6 \\
\hline
\end{tabular}

${ }^{*} \chi 2(4, \mathrm{~N}=4554)=14,5 ; p<0,05$

Tafla 3. Einelti og áreitni á núverandi vinnustað eftir kyni

\begin{tabular}{llccc}
\hline & & Fjöldi & $\begin{array}{c}\text { Já } \\
\%\end{array}$ & $\begin{array}{c}\text { Nei } \\
\%\end{array}$ \\
\hline $\begin{array}{l}\text { Hefur pú orðið fyrir einelti á núverandi vinnustað á } \\
\text { síðastliðnum tveimur árum? }\end{array}$ & Allir & 4236 & 7,8 & 92,2 \\
& Konur & 3455 & 8,0 & 92,0 \\
& Karlar & 781 & 6,7 & 93,3 \\
\hline Hefur pú orðið fyrir kynferðislegri áreitni á núver- & Allir & 4238 & 2,1 & 97,9 \\
andi vinnustað á síðastliðnum tveimur árum? & Konur & 3460 & 2,2 & 97,8 \\
& Karlar & 778 & 1,5 & 98,5 \\
\hline $\begin{array}{l}\text { Hefur pú orðið fyrir kynbundinni áreitni á núverandi } \\
\text { vinnustað á síðastliðnum tveimur árum? }\end{array}$ & Allir & 4195 & 2,2 & 97,8 \\
& Konur & 3423 & 2,4 & 97,6 \\
\hline
\end{tabular}

\subsection{Tengsl félagslegs stuðnings, starfsánægju, eineltis og áreitni á vinnustað}

Tafla 4 sýnir tengsl félagslegs stuðnings, starfsánægju, eineltis og áreitni á vinnustað. Sterkust voru tengslin milli félagslegs stuðning og starfsánægju, miðlungs sterk jákvæð tengsl $(r=0,45)$ og einnig mældust veik neikvæð tengsl við einelti $(r=-0,21)$ og kynbundna áreitni $(r=-0,10)$. Petta pýðir að eftir pví sem félagslegi stuðningurinn var meiri, peim mun 
hærra hlutfall svarenda var oftar ánægðara í starfi. Einnig komu fram neikvæð veik tengsl milli starfsánægju og eineltis á vinnustað $(r=-0,17)$.

Tafla 4. Tengsl félagslegs stuðnings, starfsánægju, eineltis og áreitni á vinnustað

\begin{tabular}{lccccccc}
\hline & 1 & 2 & 3 & 4 & 5 & 6 & 7 \\
\hline 1. Félagslegur stuðningur & - & - & - & - & - & - & - \\
2. Félagslegur stuðningur vinnufélaga & - & - & - & - & - & - & - \\
3. Félagslegur stuðningur yfirmanna & - & - & - & - & - & - & - \\
4. Starfsánægja & $0,453^{* *}$ & $0,363^{* *}$ & $0,453^{* *}$ & - & - & - & - \\
5. Einelti & $-0,210^{* *}$ & $-0,175^{* *}$ & $-0,199^{* *}$ & $-0,165^{* *}$ & - & - & - \\
6. Kynferðisleg áreitni & 0,004 & $-0,030^{*}$ & $-0,045^{* *}$ & $-0,009$ & $0,096^{* *}$ & - & - \\
7. Kynbundin áreitni & $-0,103^{* *}$ & $-0,077^{* *}$ & $-0,103^{* *}$ & $-0,075^{* *}$ & $0,092^{* *}$ & $0,118^{* *}$ & - \\
\hline
\end{tabular}

** marktækt miðað við 99\% öryggismörk

Óháð t-próf var framkvæmt til að skoða nánar sambandið á milli félagslegs stuðnings á vinnustað og eineltis og áreitni á núverandi vinnustað. Niðurstöðurnar sýndu að peir sem höfðu orðið fyrir einelti á núverandi vinnustað töldu sig sjaldnar fá félagslegan stuðning $(M=3,3 ; s f=0,9)$ en peir sem höfðu ekki orðið fyrir einelti á núverandi vinnustað $(M=4,1$; $s f=0,7),\left(t_{(4238)}=18,2 ; p<0,05\right)$. Peir sem höfðu orðið fyrir kynferðislegri áreitni á núverandi vinnustað töldu sig einnig sjaldnar fá félagslegan stuðning á vinnustaðnum $(M=3,8 ; s f=$ $0,9)$ en peir sem ekki höfðu orðið fyrir kynferðislegri áreitni $(M=4,1 ; s f=0,8),\left(t_{(88)}=2,5 ; p\right.$ $<0,05)$. Félagslegur stuðningur mældist einnig minni hjá peim sem höfðu orðið fyrir kynbundinni áreitni á núverandi vinnustað $(M=3,4 ; s f=1,0)$ en peim sem ekki höfðu orðið fyrir kynbundinni áreitni $(M=4,1 ; s f=0,8),\left(t_{(98)}=6,4 ; p<0,05\right)$.

\section{Umræður og ályktun}

Markmið pessarar rannsóknar var að skoða félagslegan stuðning á vinnustaðnum hjá starfsfólki íslenskra sveitarfélaga og tengsl hans við starfsánægju, einelti og kynferðislega og kynbundna áreitni á núverandi vinnustað. Niðurstöðurnar sýna að félagslegur stuðningur hafði jákvæð miðlungs sterk tengsl við starfsánægju starfsfólksins og neikvæð veik tengsl við einelti og kynferðislega og kynbundna áreitni á vinnustað. Pessi rannsókn styður niðurstöður annarra rannsókna að góður félagslegur stuðningur tengist ánægju í starfi (Kucharska og Bedford, 2019, Ng og Sorensen, 2008; Pinna ofl., 2020; Yuh og Choi, 2017) og gefur til kynna að félagslegur stuðningur sé verndandi páttur gegn óæskilegri hegðun á vinnustað eins og einelti og kynferðislegri áreitni og kynbundinni áreitni. Sú niðurstaða er í samræmi við niðurstöður rannsóknar Hjördísar Sigursteinsdóttur og félaga (2020) og Nielsen og félaga (2020). Starfsfólk sem hefur orðið fyrir einelti og/eða áreitni á vinnustað telur að pað fái sjaldnar félagslegan stuðning á vinnustað frá yfirmönnum og vinnufélögum en pað starfsfólk sem ekki hefur orðið fyrir pess háttar óæskilegri hegðun (Ásta Snorradóttir o.fl., 2020; Hjördís Sigursteinsdóttir, 2013).

Stjórnendur hafa á síðustu árum gert sér í auknum mæli grein fyrir pví hversu áríðandi pað er að stuðla að félagslegum stuðningi á vinnustaðnum sem getur síðan leitt til meiri starfsánægju starfsmanna og betri samskipta. Mikilvægt er að vinnuumhverfi starfsfólks sé pannig аð pað einkennist af gagnkvæmri virðingu í samskiptum og að starfsfólk sé verndað gegn einelti og áreitni á vinnustað eins og bæði Ana (2015) og Gransta (2015) benda á. Kwan og félagar (2016) varpa ábyrgðinni svolítið á stjórnendur og pað sé hlutverk peirra að skapa vinnuumhverfi par sem félagslegur stuðningur og starfsánægja svífur yfir vötnum og kveður niður einelti og hvers kyns áreiti. Hægt er að taka undir pað sjónarmið enda kemur fram í reglugerðinni um aðgerðir gegn einelti, kynferðislegri áreitni, kynbundinni áreitni og ofbeldi á vinnustöðum (nr. 1009/2015) að pað sé óheimilt 
að leggja annað starfsfólk í einelti eða áreita á íslenskum vinnustöðum og par eru einnig settar fram kvaðir á stjórnendur um að bregðast við slíkri hegðan og tryggja góða líðan starfsfólks á vinnustað.

Niðurstöðurnar sýna að starfsfólk sveitarfélaga taldi að yfirmenn og vinnufélagar veiti peim í langflestum tilvikum stuðning og hjálp með verkefni ef á parf að halda sem og séu fúsir til að hlusta á vandamál sem við er að glíma í vinnunni. Petta eru jákvæðar niðurstöður fyrir stjórnendur vinnustaða sveitarfélaganna pví eins og Lan og félagar (2018) benda á pá hefur upplifun starfsfólks af félagslegum stuðningi áhrif á jákvæðar tilfinningar gagnvart vinnunni og Kiema-Junes og félagar (2020) að félagslegur stuðningur tengist helgun í starfi pannig að eftir pví sem félagslegur stuðningur er meiri pví meira er starfsfólkið helgað starfi sínu. Niðurstöðurnar sýna jafnframt að hærra hlutfall kvenna en karla taldi sig fá oftar félagslegan stuðning á vinnustað frá bæði vinnufélögum og yfirmönnum. Раð kemur í raun ekki á óvart par sem rannsókn Hjördísar Sigursteinsdóttur frá árinu 2013 sýndi að konur meta að pær fái oftar félagslegan stuðning en karlar sem og rannsóknir Beerh og félaga (2003) og Fuhrer og félaga (1999), en pær rannsóknir sýna einnig að karlar fá meira út úr peim félagslega stuðningi sem peir pó fá en konur sem er í raun mjög athyglisverð niðurstaða.

I pessari rannsókn mældist einelti um 8\% og kynferðisleg áreitni sem og kynbundin áreitni $2 \%$. Hlutfall peirra sem greindu frá pví að hafa orðið fyrir einelti á núverandi vinnustað er pví mun lægra en aðrar íslenskar rannsóknir hafa greint frá á síðustu árum par sem hlutfallið hefur mælst á bilinu 10-20\% (sjá t.d. Ásta Snorradóttir o.fl., 2020; Hjördís Sigursteinsdóttir, 2013; Hjördís Sigursteinsdóttir, 2017; Hjördís Sigursteinsdóttir o.fl., 2020). Hvað kynferðislega áreitni og kynbundna áreitni varðar pá sýna pessar niðurstöður svipaðar niðurstöður og komu fram í rannsókn Hjördísar Sigursteinsdóttur (2017) meðal félagsmanna Kennarasambands Î́slands (KÍ). Pað ætti í raun ekki að koma á óvart par sem stór hluti starfsfólks sveitarfélaga eru grunnskólakennarar og leikskólakennarar. Hvorki í pessari rannsókn né rannsókninni meðal félagsmanna KÍ kom fram marktækur munur á einelti eða áreitni eftir kynferði. Hins vegar sýnir rannsókn Ástu Snorradóttur og félaga sem gerð var meðal fólks úr ýmsum starfsstéttum að $16 \%$ pátttakenda hafi orðið fyrir kynferðislegri áreitni á vinnustað, 10\% fyrir kynbundinni áreitni og um 20\% fyrir einelti. Leiða má líkum að pví að meðal stórra starfsstétta sem starfa á vinnustöðum sveitarfélaga, eins og grunnskólakennara og leikskólakennara, sé algengi eineltis og áreitni minna en meðal annarra starfsstétta.

Styrkleikur rannsóknarinnar felst í pví að hér er um að ræða pýðisrannsókn par sem öllu starfsfólki sveitarfélaganna prettán var boðið að taka pátt í rannsókninni. Pað fengust svör frá meira en helmingi starfsfólksins (54,2\%) sem teljast má gott, sem og að pátttakendur í rannsókninni endurspegla vel pann mikla kynjahalla sem vinnustaðir sveitarfélaga hafa. Pó ber að hafa í huga að hér er um að ræða pversniðs rannsókn sem sýnir niðurstöður á aðeins einum tímapunkti. Í ljósi niðurstaðanna væri mjög gagnlegt að kanna síðar hvort og pá hvernig viðhorf starfsfólksins próast, sérstaklega í ljósi Covid-19 sem væntanlega hefur áhrif á vinnustaði sveitarfélaganna.

Hagnýtt gildi rannsóknarinnar felst í aukinni pekkingu á mikilvægi félagslegs stuðnings á vinnustað og tengsl hans við óæskilega hegðun eins og einelti og áreitni á vinnustað. Álykta má út frá niðurstöðum rannsóknarinnar að félagslegur stuðningur vinnufélaga og yfirmanna sé mikilvægur páttur sem tengist starfsánægju starfsfólks sveitarfélaga og sé verndandi páttur í baráttunni gegn einelti og áreitni á vinnustað. Pað segir okkur að stjórnendur og peir sem bera ábyrgð á vellíðan starfsmanna á vinnustað ættu að leggja áherslu á félagslegan stuðning á vinnustað, ekki síst á umbrotatímum og á vinnustöðum par sem sálfélagslegt vinnuumhverfi er erfitt. 


\section{Heimildir}

Ahmad, K. Z. og Veerapandian, K. (2012). The mediating effect of person-environment fit on the relationship between organisational culture and job satisfaction. International Journal of Psychological Studies, 4, 91-102. doi:10.5539/ijps.v4n1p91

Aletraris, L. (2010). How satisfied are they and why? A study of job satisfaction, job rewards, gender and temporary agency workers in Australia. Human Relations, 63, 1129-1155. doi:10.1177/0018726709354131

ANA. (2015). Incivility, Bullying and Workplace Violence: A Position Statement. American Nursing Association, 2. Sótt af: http://www.nursingworld.org/DocumentVault/PositionStatements/Practice/Position-Statement-on-IncivilityBullying-and-Workplace-Violence.pdf

Ásta Snorradóttir, Guðbjörg Andrea Jónsdóttir, Guðný Gústafsdóttir, Guðný Bergpóra Tryggvadóttir, Hrafnhildur Snæfríðar-og Gunnarsdóttir og Margrét Valdimarsdóttir. (2020). Valdbeiting á vinnustað: Rannsókn á algengi og eðli eineltis og áreitni á íslenskum vinnumarkaði. Félagsvísindastofnun Háskóla Íslands. Sótt af: https://www.stjornarradid.is/library/04-Raduneytin/Felagsmalaraduneytid/Valdbeiting\%20\%C3\%A1\%20 vinnusta\%C3\%B0_\%20-\%20Copy\%20(1).pdf

Ásta Snorradóttir og Kristinn Tómasson. (2018). Einelti á íslenskum vinnustöðum. Tímarit um viðskipti og efnahagsmál, 15 (2), 47-59. doi:10.24122/tve.a.2018.15.2.3

Beehr, T. A., Farmer, S. J., Glazer, S., Gudanowski, D. M. og Nair, V. N. (2003). The enigma of social support and occupational stress: source congruence and gender role effects. Journal of Occupational Health Psycholo$g y, 8,220-231$. doi:10.1037/1076-8998.8.3.220

Cobb, S. (1976). Social support as a moderator of life stress, Psychosomatic Medicine, 38(5), $300-314$. doi:10.1097/00006842-197609000-00003

Cohen, S. (1988). Psychosocial models of the role of social support in the etymology of physical disease. Health Psychology, 7, 269-297. doi.10.1037/0278-6133.7.3.269

Bhanthumnavian, D. (2003). Perceived social support from supervisor and group members' psychological and situational characteristics as predictors of subordinate performance in Thai work units. Human Resource Development Quarterly, 14, 79. doi.10.1002/hrdq.1051

Borzaga, C. og Tortia, E. (2006). Worker motivations, job satisfaction, and loyalty in public and nonprofit social services. Non-profit and Voluntary Sector Quarterly, 35, 225-248. doi:10.1177/0899764006287207

Durst, S. L. og DeSantis, V. S. (1997). The determinants of job satisfaction among federal, state, and local government employees. State and Local Government Review, 29, 7-16. doi:10.1177/0160323X9702900101

Ellickson, M. C. og Logsdon, K. (2002). Determinants of job satisfaction of municipal goverment employees. Public Personnel Management, 31(3), 343-358. doi:10.1177/009102600203100307

Ellickson, M. C. og Logsdon, K. (2001). Determinants of job satisfaction of municipal government employees. State and Local Government Review, 33, 173-184. doi:10.1177/0160323X0103300302

Fang, L., Hsiao, L., Fang, S. og Chen, B. (2021). Workplace bullying, personality traits and health among hospital nurses: The mediating effect of social support. Journal of Clinical Nursing. doi: 10.1111/jocn.15881.

Feng, Z. og Savani, K. (2020). Covid-19 created a gender gap in perceived work productivity and job satisfaction: implications for dual-career parents working from home. Gender in Management: An International Journal, 35, 719-736. doi.10.1108/GM-07-2020-0202.

Fujishiro, K. og Heaney, C.A. (2007). Justice at work, job stress, and employee health. Health Education \& Behavior. doi:10.1177/1090198107306435

Fuhrer, R. og Stansfeld, S. A. (2002). How gender affects patterns of social relations and their impact on health: a comparison of one or multiple sources of support from "close persons". Social Science E Medicine, 54, 811825. doi:10.1016/s0277-9536(01)00111-3

Fuhrer, R., Stansfeld, S. A., Chemali, J. og Shipley, M.J. (1999). Gender, social relations, and mental health: prospective findings from an occupational cohort (Whitehall II study). Social Science E Medicine, 48, 77-87. doi:10.1016/s0277-9536(98)00290-1

Giorgi, G., León-Perez, J.M., Montani, F., Fernández-Salinero, S., Ortiz-Gómez, M., Ariza-Montes, A., Arcangeli, G. og Mucci, N. (2020). Fear of Non-Employability and of Economic Crisis Increase Workplace Harassment through Lower Organizational Welfare Orientation. Sustainability, 12, 3876. doi: 10.3390/su12093876

Gransta, K. (2015). Nurse against nurse: Horizontal bulling in the nursing profession. Journal of Healthcare Management, 60(4), 249-257. doi: 10.1097/00115514-201507000-00006

Guðbjörg Linda Rafnsdóttir og Kristinn Tómasson. (2004). Einelti á vinnustað, vinnuskipulag og líðan starfsmanna. Læknablaðið, 90(12), 847-851.

Hayes, B., Bonner, A. og Pryor, J. (2010). Factors contributing to nurse job satisfaction in the acute hospital setting: A review of recent literature. Journal of Nursing Management, 18, 804-814. doi:10.1111/j.13652834.2010.01131.x

Hjördís Sigursteinsdóttir. (2010). Líðan og heilsa starfsfólks sveitarfélaga á tímum efnahagsprenginga - Skiptir félagslegur stuðningur máli? Djóðarspegill 2010, Reykjavík: Félagsvísindastofnun Háskóla Îslands.

Hjördís Sigursteinsdóttir. (2013). Einelti og líðan starfsfólks sveitarfélaga á tímum efnahagsprenginga. Stjórnmál og stjórnsýsla, 9(2), 439-454. doi:10.13177/irpa.a.2013.9.2.9 
Hjördís Sigursteinsdóttir. (2017). Einelti, áreitni og ofbeldi á vinnustað: Könnun meðal félagsmanna Kennarasambands Íslands. Netla - Veftímarit um uppeldi og menntun: Sérrit 2017 - Menntavika 2017. Sótt af http:// netla.hi.is/serrit/2017/menntavika_2017/006.pdf.

Hjördís Sigursteinsdóttir, Guðbjörg Linda Rafnsdóttir og Guðbjörg Andrea Jónsdóttir. (2020). Bullying and harassment in downsized Workplaces: what can we learn from the 2008 Icelandic Economic Collapse? International Journal of Environmental Research and Public Health, 17, 7180. doi: 10.3390/ijerph17197180

Hobfoll, S. E. og Stokes, J. P. (1988). The process and mechanics of social support. Í S. Duck, D. F. Hay, S. E. Hobfall, W. Ickes og B. M. Montgomery (ritstjórar), Handbook of personal relationships: Theory, research and interventions (bls. 497-517). Oxford: John Wiley \& Sons.

Johnson, J. V. og Hall, E. M. (1988). Job strain, workplace social support, and cardiovascular disease; a cross-sectional study of a random sample of the Swedish working population. American Journal of Public Health, 78(10), 1336-1342. doi:10.2105/AJPH.78.10.1336

Kalleberg, A. L. (1977). Work values and job rewards: A theory of job satisfaction. American Sociological Review, 42(1), 124-143. doi:10.2307/2117735

Karasek, R. (1979). Job demands, job decision, latitude and mental strain: Implication for job redesign. Administration Science Quarterly, 24, 285-311. doi:10.2307/2392498

Karasek, R. og Theorell, T. (1990). Healthy Work. Stress, Productivity, and the Reconstruction of Working Life. New York: Basic Books.

Kiema-Junes, H., Saarinen, A., Muukkonen, H., Väyrynen, S., Ala-Mursula, L. og Hintsanen, M. (2020). Dimensions of social support in the experience of work engagement in middle age: A Northern Finland Birth Cohort 1966 Study. Scandinavian Journal of Psychology. doi: 10.1111/sjop.12640

Kim, S. (2002). Participative management and job satisfaction: Lessons for management leadership, Public Administration Review, 62, 231-241. doi:10.1111/0033-3352.00173

Kim, S. (2005). Gender differences in the job satisfaction of public employees: A study of Seoul metropolitan government, Korea. Sex Roles, 52, 667-681. doi:10.1007/s11199-005-3734-6

Kucharska, W. og Bedford, D. A. D. (2019). Knowledge Sharing and Organizational Culture Dimensions: Does Job Satisfaction Matter? Electronic Journal of Knowledge Management, 17(1), 1-18. doi:10.2139/ssrn.3406496

Kwan, S. S. M., Tuckey, M. R. og Dollard, M. F. (2016). The role of the psychosocial safety climate in coping with workplace bullying: A grounded theory and sequential tree analysis. European Journal of Work and Organizational Psychology, 25(1), 133148. doi:10.1080/1359432X.2014.982102

Lan, W. J., Huang, D. W., He, M. Y., Wang, Z. J. og Zeng, L. P. (2018). Relationship among rural teachers' social support, work family balance and job satisfaction. Modern Preventive Medicine, 45(5), 93-97.

Locke, J. (1969). What is Job Satisfaction? Organizational Behavoiur and Human Performance, 4,309-336.

McGuire, G. M. (2007). Intimate work: A typology of the social support that workers provide to their network members. Work and Occupations, 34(2), 125-147. doi:10.1177/0730888406297313

Mérida-López, S., Extremera, N., Quintana-Ortis, C. og Rey, L. (2019). In pursuit of job satisfaction and happiness: Testing the interactive contribution of emotion-regulation ability and workplace social support. Scandinavian Journal of Psychology, 60, 59-66. doi: 10.1111/sjop.12483

Ng, T. W. H. og Sorensen, K. L. (2008). Toward a Further Understanding of the Relationships Between Perceptions of Support and Work Attitudes: A Meta-Analysis. Group E Organization Management, 33(3), 243-268. doi:10.1177/1059601107313307

Nielsen, M. B., Christensen, J. O., Finne, L. B. og Knardahl, S. (2020). Workplace bullying, mental distress, and sickness absence: the protective role of social support. International Archives of Occupational and Environmental Health, 93 (1), 43-53. doi:10.1007/s00420-019-01463-y

Nielsen, M.B. og Einarsen, S. (2018). What we know, what we do not know, and what we should and could have known about workplace bullying: An overview of the literature and agenda for future research. $\mathrm{Ag}$ gression and Violent Behavior, 42, 71-83. doi:10.1016/j.avb.2018.06.007.

Pinna, R., De Simone, S., Cicotto, G. og Malik, A. (2020). Beyond organisational support: Exploring the supportive role of co-workers and supervisors in a multi-actor service ecosystem. Journal of Business Research, 121, 524-534. doi:10.1016/j.jbusres.2020.02.022

Plaisier, I., De Bruijn, J. G., de Graaf, R., ten Have, M., Beekman, A. T. og Penninx, B. W. (2007). The contribution of working conditions and social support to the onset of depressive and anxiety disorders among male and female employees. Social Science E Medicine, 64(2), 401-410. doi:10.1016/j.socscimed.2006.09.008

Rasmussen, M.B., Hansen, T. og Nielsen, K.T. (2011). New tools and strategies for the inspection of the psychosocial working environment: The experience of the Danish working environment authority. Safety Science, 49, 565-574. doi:10.1016/J.SSCI.2010.06.002

Reglugerð um aðgerðir gegn einelti, kynferðislegri áreitni, kynbundinni áreitni og ofbeldi á vinnustöðum nr. $1009 / 2015$.

Rossiter, L. og Sochos, A. (2018). Workplace Bullying and Burnout: The Moderating Effects of Social Support, Journal of Aggression, Maltreatment E Trauma, 27, 386-408. doi:10.1080/10926771.2017.1422840

Rousseau, V. og Aubé C. (2010). Social support at work and affective commitment to the organization: The 
moderating effect of job resource adequacy and ambient conditions. The Journal of Social Psychology, 150(4), 321-340. doi:10.1080/00224540903365380

Saari, L. M. og Judge, T.A. (2004). Employee attitudes and job satisfaction. Human resource Management, 43(4), 395-407. doi:10.1002/hrm.20032

Samband íslenskra sveitarfélaga. (e.d.). Kjara- og starfsmannamál - tölulegar upplýsingar. Sótt af http://www. samband.is/verkefnin/kjara-og-starfsmannamal/

Schwarzer, R. og Gutiérrez-Dona, B. (2005). More spousal support for men than for women: a comparison of sources and types of support. Sex roles, 52, 523-532. doi:10.1007/s11199-005-3718-6

Seiger, A. og Wiese, B. S. (2009). Social support from work and family domains as an antecedent or moderator of work-family conflicts? Journal of Vocational Behavior, 75, 26-37. doi:10.1016/J.JVB.2009.03.001

Steijn, B. (2004). Human resource management and job satisfaction in the Dutch public sector. Review of Public Personnel Administration, 24(4), 291-303. doi:10.1177/0734371X04269187

Walen, H. R. og Lachman, M. E. (2000). Social support and strain from partner, family, and friends: Costs and benefits for men and women in adulthood. Journal of Social and personal Relationships, 17(1), 5-30. doi:10.1177/0265407500171001

Wright, B. E. og Davis, B. S. (2003). Job satisfaction in the public sector: The role of the work environment, American Review of Public Administration, 33(1), 70-90. doi:10.1177/0275074002250254

Yang, J. R. og Katz, B. (2020). Promising Practices for Addressing Harassment in the STEM Workplace - How to Lead in Today's Environment. Urban Institute. Sótt af: https://ethicsandequitycenter.org/wp-content/ uploads/2020/04/Promising_Practices_for_Addressing_Harassment_in_the_STEM_Workplace.pdf

Yuh, J. og Choi, S. (2017). Sources of social support, job satisfaction, and quality of life among childcare teachers. The Social Science Journal, 54(4), 450-457. doi:10.1016/j.soscij.2017.08.002

Zapf, D. (1999). Organisational, work group related and personal causes of mobbing/ bullying at work. International Journal of Manpower, 20(1/2), 70-85. doi:10.1108/01437729910268669 